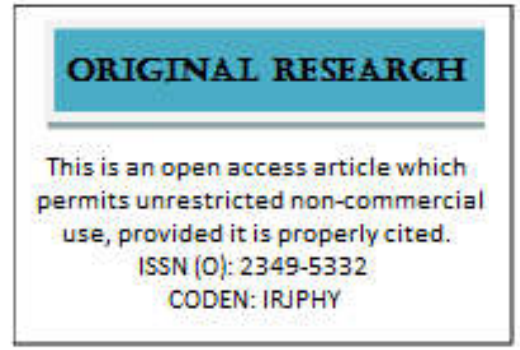

SSN (O): $2349-5332$
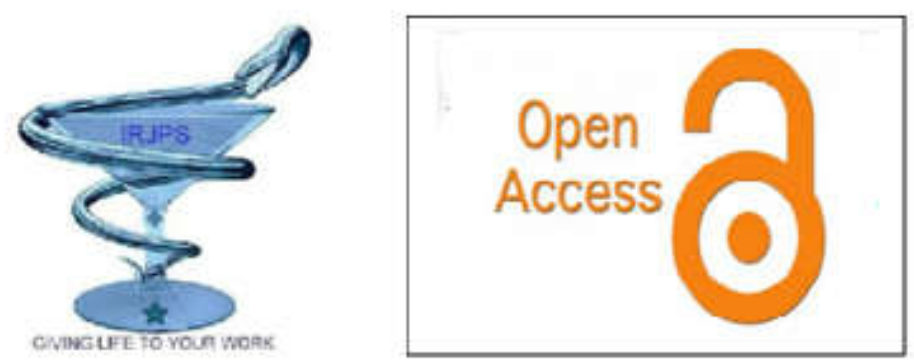

\title{
PHYTOCHEMICAL ANALYSIS AND MINERAL COMPOSITION OF MAJIDEA ZANQUEBARICA J. KRIK. EX OLIV (SAPINDACEAE)
}

\section{Shyamalagowri Shanmugasundaram}

Post Graduate and Research Department of Botany, Pachaiyappas College, Chenna, India

\begin{abstract}
Phytochemical analyses and mineral compositions of Majidea zanquebarica, Bark hexane extract were administered with a view to assess the therapeutic values and safety of the plants in ethnomedicine. The outcomes uncovered that the higher concentration of bioactive constituents, including estimation of the mineral examination and phytochemicals have demonstrated that higher measure of phenols $(7.2 \pm 0.37 \mathrm{mg} / \mathrm{g})$, saponins $(22.86 \pm 0.3$ $\mathrm{mg} / \mathrm{g})$, flavonoids $(7.8 \pm 0.43 \mathrm{mg} / \mathrm{g})$, tannins $(5.7 \pm 0.50 \mathrm{mg} / \mathrm{g})$ and alkaloids $(3.62 \pm 0.77 \mathrm{mg} / \mathrm{g})$ was found. The mineral investigation shows that the higher concentrations of calcium, magnesium, iron, nitrogen. The outcomes demonstrated that the plants hold tremendous promise in giving the variable optional secondary metabolites and mineral supply that would improve the remedial process of inadequate health.
\end{abstract}

KEYWORDS: Phytochemical analyses, mineral elements, Majidea zanquebarica, Sapindaceae.

Corresponding Author: S. Shyamala Gowri E-mail: shyamalagowri1985@gmail.com
Indian Research Journal of Pharmacy and Science; 25(2020)2154-2160; Journal Home Page: https://www.irjps.in DOI: 10.21276/irjps.2020.7.2.7 


\section{INTRODUCTION}

Medicinal plants have been used to treat human diseases for thousands of years because they have vast and different assortment of organic compounds that can produce a definite physiological action on the human body. Most important of such compounds are alkaloids, tannins, flavonoids, terpenoids, saponins and phenolic compounds. Pharmacists are interested in these compounds because of their therapeutic performance and low toxicity $^{1}$.

Phytochemicals are a field of growing interest, both in science and in commerce. As is now usually documented, many plant compounds and pigments have effects on animals and human beings. There is an immense attempt now to revise and understand at a fundamental level and considerable health effects of these compounds. This field is maturing and the health effects of these compounds are now receiving the careful investigation they demand at both a chemical and molecular biological level. Identifying their health effects are active areas of scientific examination ${ }^{2}$.

Secondary metabolites have been considering using the approach of classical phytochemistry, focused on knowledge of the chemical components of a plant. Often, plant secondary metabolites may be referred to as natural products, in which case they elicit effects on other organisms ${ }^{3,1}$. Secondary metabolites can be classified according to their chemical structure, composition, solubility in different solvents, or on the basis of their synthesis pathway. A simple classification, based on chemical structure, includes three main groups: terpenes-composed almost totally of carbon and hydrogen and as well as plant volatiles, cardiac glycosides, carotenoids and sterols, phenolics-with the common feature of having one or more phenol rings and including phenolic acids, coumarins, flavonoids, tannins and lignins, and nitrogencontaining compounds which are tremendously diverse, including alkaloids and glucosinolates ${ }^{4}$.

Conventional healers in rural areas in many developing countries use medicinal plants as traditional medicines ${ }^{5,6}$. They claim that medicinal plants, when compared with synthetic medicines, they are more effective, cheaper, and have less side effects than synthetic drugs. Low - income people in developing countries use plants for the treatment of common infections ${ }^{7}$.

Ethnomedical information discovered that extracts from members of the family Sapindaceae are commonly used for the action of boils, ulcers, pain, dermatological troubles, wounding healing, diarrhoea and dysentery. Many species in this family have been reported to possess a number of biological and pharmacological activities ${ }^{8,9}$. In this sense, hitherto unexploited species of Sapindaceae, Majidea zanquebarica wads selected for the phytochemical and mineral analysis. It is therefore of major interest to evaluate the composition of some metallic elements in herbal plants, because at elevated levels, these metals can be dangerous and toxic ${ }^{10}$. Although some trace metals may have both curative and preventive roles in combating diseases. The current investigation was designed to assess the phytochemical and mineral composition of M. zanquebarica.

\section{MATERIALS AND METHODS Preparation of extracts}

The dried powder of aerial parts (barks, pod, leaf and seeds) (2 $\mathrm{kg}$ ) were soaked individually at room temperature in hexane for $72 \mathrm{hrs}$. The extract was suction filtered using Whatmann filter paper. This was repeated for 2 to 3 times and similar extracts were pooled together and concentrated at 40 to $45^{\circ} \mathrm{C}$ under reduced pressure using vacuum rotary evaporator type 350 . The concentrated crude hexane extract was subjected to phytochemical and Element analysis $^{11,12}$.

\section{PHYTOCHEMICAL ANALYSIS}

\section{Qualitative phytochemical analysis}

A preliminary phytochemical analysis to screen the samples for the presence of phytochemical components such as alkaloids, glycosides, phlobatanins, phenols, saponins and tannins was performed according to the method ${ }^{13,14,15,16}$. 


\section{Quantitative phytochemicals \\ Determination of alkaloids}

$5 \mathrm{~g}$ of plant sample was weighed into a 250 $\mathrm{ml}$ beaker and dispersed into $200 \mathrm{ml}$ of $10 \%$ acetic acid solution in ethanol. The filtrate was then evaporated to one quarter of its original volume on a hot plate. Concentrated ammonium hydroxide was added drop wise in order to precipitate the extract. The whole solution was allowed to settle and the precipitate was collected and washed with dilute ammonium hydroxide and then filtered. The residue is the alkaloid which was dried and weighed ${ }^{17}$.

Total flavonoid content was expressed as gram quercetin equivalent

Total flavonoid content was measured by the aluminum chloride colorimetric assay ${ }^{18}$. The absorbance was read $510 \mathrm{~nm}$. Three replications were performed for each extract. Total flavonoid content was expressed as gram catechin equivalent The value of optical density was used to calculate the total flavonoid content present in the sample.

\section{Determination of total phenols}

Total phenol was quantified and expressed as gallic acid equivalents ${ }^{19}$. About $3.9 \mathrm{ml}$ of distilled water and $0.5 \mathrm{ml}$ of Folin-ciocalteau reagent were added to $0.1 \mathrm{ml}$ of extract in a tube and incubated at room temperature for $3 \mathrm{~min}$, after which $2 \mathrm{ml}$ of $20 \%$ sodium carbonate was added to this and kept at boiling water bath for $1 \mathrm{~min}$. Phenol reacts with phosphomolybdic acid in the Folin-Ciocalteau reagent in alkaline medium and produce a blue colored complex (molybdenum blue) that can be read colorimetrically at $650 \mathrm{~nm}$.

\section{Determination of saponins}

$20 \mathrm{~g}$ of each sample was dispersed in $200 \mathrm{ml}$ of $20 \%$ ethanol. The suspension was heated over a hot water bath for $4 \mathrm{~h}$ with continuous stirring at about $55^{\circ} \mathrm{C}$. The mixture was filtered and the residue re-extracted with another $200 \mathrm{ml}$ of $20 \%$ ethanol. The combined extracts were reduced to $40 \mathrm{ml}$ over a water bath at about $90^{\circ} \mathrm{C}$. The concentrate was transferred into a $250 \mathrm{ml}$ separatory funnel and $20 \mathrm{ml}$ of diethyl ether was added and shaken vigorously. The aqueous layer was recovered and the purification process was repeated. $60 \mathrm{ml}$ of n-butanol was added. The combined n-butanol extracts were washed twice with $10 \mathrm{ml}$ of $5 \%$ aqueous sodium chloride. The remaining solution was heated in a water bath. After evaporation, the samples were dried in the oven to a constant weight. The saponin contents were calculated in percentage ${ }^{20}$.

\section{Elemental analysis}

The major elements comprising calcium, potassium and trace elements (iron and zinc) were determined according to the method with slight modification $^{21}$. The ground samples were sieved with a $2 \mathrm{~mm}$ rubber sieve and $2 \mathrm{~g}$ of each of the plant samples were subjected to dry ashing in a wellcleaned porcelain crucible at $550^{\circ} \mathrm{C}$ in a muffle furnace. The resultant ash was dissolved in $5 \mathrm{ml}$ of $\mathrm{HNO}_{3} / \mathrm{H}_{2} \mathrm{O}_{2}$ (1:1) and heated gently on a hot plate until brown fumes disappeared. To the remaining material in each crucible, $5 \mathrm{ml}$ of deionized water was added and heated until a colorless solution was obtained. The mineral solution in each crucible was transferred into a $100 \mathrm{ml}$ volumetric flask by filtration through a Whatmann filter paper and the volume was made to mark with deionized water. This solution was used for elemental analysis by Atomic Absorption Spectrophotometer (AAS). The concentration of each element was calculated on percentage of dry matter.

\section{RESULTS AND DISCUSSION}

Phyto medicines are an important component derived from different parts of the plants with diverse applications in pharmaceutical and herbal industry. Development of herbal remedies is more popular nowadays due to less side effects. Presence of bioactive secondary metabolites in the medicinal plants are more responsible to cure several diseases in mankind ${ }^{22}$.

The preliminary phytochemical analysis of bark extract hexane of $M$. zanquebarica is represented in Table 1. M. zanquebarica bark extract revealed the high degree of precipitation $(+++)$ for flavonoids, saponins, phenols and terpenoids, moderate degree of precipitation $(++)$ for steroids and tannins. Alkaloids, Carbohydrate and glycosides showed low degree of precipitation $(+)$. This may be due to various degrees of solubility of different solvents for different phytoconstituents. It is well 
documented fact that the presence of these chemicals is associated with various medicinal properties ${ }^{23}$.

Quantitative phytochemical estimation of the phytochemicals have shown that higher amount of phenols $(7.2 \pm 0.37 \mathrm{mg} / \mathrm{g})$, saponins $(22.86 \pm 0.3$ $\mathrm{mg} / \mathrm{g})$, flavonoids $(7.8 \pm 0.43 \mathrm{mg} / \mathrm{g})$, tannins $(5.7 \pm$ $0.50 \mathrm{mg} / \mathrm{g})$ and alkaloids $(3.62 \pm 0.77 \mathrm{mg} / \mathrm{g})$ was found. Similar results were observed in methanolic extracts of Cassia coriaria ${ }^{24}$.

Table 1: Preliminary phytochemical activity of Majidea zanguebarica.

\begin{tabular}{|c|c|c|}
\hline SL. NO. & PHYTOCHEMICALS & BARK \\
\hline \multirow[t]{4}{*}{1} & $\begin{array}{l}\text { Alkaloids } \\
\text { a) Mayer's test }\end{array}$ & + \\
\hline & b) Wagner's test & - \\
\hline & c) Hager's test & - \\
\hline & c) Dragendroff's test & + \\
\hline \multirow[t]{2}{*}{2} & $\begin{array}{l}\text { Flavonoids } \\
\text { a) Shinoda test }\end{array}$ & +++ \\
\hline & b) Alkaline reagent test & +++ \\
\hline \multirow[t]{5}{*}{3} & $\begin{array}{l}\text { Carbohydrates and glycosides } \\
\text { a) Molish test }\end{array}$ & + \\
\hline & b) Fehling's test & + \\
\hline & c) Barfoed's test & + \\
\hline & d) Borntrager's test & + \\
\hline & e) Legal test & + \\
\hline 4 & Saponin by foam test & +++ \\
\hline \multirow[t]{2}{*}{5} & $\begin{array}{l}\text { Phenols } \\
\text { a) Ferric chloride }\end{array}$ & +++ \\
\hline & b) Gelatin test & +++ \\
\hline \multirow[t]{2}{*}{6} & $\begin{array}{l}\text { Terpenoids } \\
\text { a) Salkowski test }\end{array}$ & +++ \\
\hline & b) Liberman Burchard reaction & +++ \\
\hline \multirow[t]{2}{*}{7} & $\begin{array}{l}\text { Tannins } \\
\text { a) } \mathrm{FeCl}_{3} \text { test }\end{array}$ & ++ \\
\hline & b) Lead acetate test & ++ \\
\hline \multirow[t]{2}{*}{8} & $\begin{array}{l}\text { Steroids } \\
\text { a) Salkowski test }\end{array}$ & ++ \\
\hline & b) Liberman Burchard reaction & ++ \\
\hline
\end{tabular}


Table 2: Quantitative phytochemical analysis showed the presence of bioactive compounds in the hexane bark extract of $M$. zanquebarica

\begin{tabular}{|c|c|}
\hline \multirow{2}{*}{$\begin{array}{l}\text { Phytochemicals } \\
(\boldsymbol{\mu g} / \mathbf{m g} \text { extract })\end{array}$} & Quantity $\mathbf{m g} / \mathbf{g}$ \\
\cline { 2 - 2 } & Hexane extract \\
\hline Alkaloids & $3.62 \pm 0.77$ \\
\hline Phenols & $7.20 \pm 0.37$ \\
\hline Flavonoids & $7.80 \pm 0.43$ \\
\hline Tannins & $5.70 \pm 0.50$ \\
\hline Saponins & $22.86 \pm 0.30$ \\
\hline
\end{tabular}

The considerable amount of various elements such as: aluminum $(\mathrm{Al})$, calcium $(\mathrm{Ca})$, copper $(\mathrm{Cu})$, iron $(\mathrm{Fe})$, magnesium $(\mathrm{Mg})$, manganese $(\mathrm{Mn})$, phosphorus $(\mathrm{P})$, sulphur $(\mathrm{S})$, zinc $(\mathrm{Zn})$ have been determined from M. zanquebarica (Table 3). These elements are biologically very much important for the treatment of diverse skin diseases. The mineral analysis in bark of $M$. zanquebarica indicates the higher concentration of elements such as $\mathrm{Ca}$ (17248-19393), Mg (9536.4-9825.3), S (390.2402.2), P (173.38-226.11), Fe (84.95-130.10), Zn (56.2-61.75), Mn (26.7-29.9), $\mathrm{Cu}(14.3-16.2)$ and $\mathrm{Al}$ (7.44-8.48).

Table 3. Quantity of different elements in M. zanquebarica bark

\begin{tabular}{|l|c|}
\hline Name of the element & $\begin{array}{c}\text { Amount } \\
(\mathbf{m g} / \mathbf{k g})\end{array}$ \\
\hline Aluminum & $7.44-8.48$ \\
\hline Calcium & $17248-19393$ \\
\hline Copper & $14.3-16.2$ \\
\hline Iron & $84.95-130.10$ \\
\hline Magnesium & $9536.4-9825.3$ \\
\hline Manganese & $26.7-29.9$ \\
\hline Phosphorous & $173.38-226.11$ \\
\hline Sulphur & $390.2-402.2$ \\
\hline Zinc & $56.2-61.75$ \\
\hline
\end{tabular}

Nutritionally the valuable mineral analysis has shown that the plants were rich sources of $\mathrm{Al}, \mathrm{Ca}, \mathrm{Cu}, \mathrm{Fe}$, $\mathrm{Mg}, \mathrm{Mn}, \mathrm{P}, \mathrm{S}$ and $\mathrm{Zn}$ are presented in Table 3. A number of trace elements play an important function in the metabolism. An element is considered essential for a plant if the plant fails to grow normally and complete its life cycle in a medium adequately removed from the element, whereas in the presence of the suitable chosen concentration of that element it grows and reproduces normally ${ }^{25}$. Metals and its 
elements as well as their compounds have been used since ancient times for therapeutic as well as cosmetic effects on skin potassium is involved in maintaining proper acid-base balance and in nerve impulse transmission in the body ${ }^{26}$.

The various parts showed significant differences in the zinc and copper content, having the highest content in the stem. It is noteworthy that zinc is an essential mineral for the meta-bolism of carbohydrates, lipids and proteins ${ }^{27}$.

Manganese is an important modulator of cell functions and plays a vital role in the control of diabetes mellitus ${ }^{28}$.The importance of iron in maintaining the good health has been recognized ${ }^{29}$. The appreciable concentrations of minerals such as sodium, potassium, calcium and magnesium obtained from $M$. zanquebarica are interesting. It showed that the plant holds incredible promise in providing the variable secondary metabolites and mineral supply that could improve the curative process of ill health. These findings give quantitative estimation of the phytochemicals as well as mineral element analysis which are important in understanding the pharmacological and toxicological actions of medicinal plants.

\section{CONCLUSION}

These research have shown that the $M$. zanquebarica contained high amounts of phytoconstituents and mineral elements which could provide a scientific basis for the development of new modern medicines with different combinations of plants which can be used in the cure of many diseases ethno medicinal products. This has also been proven that the ingestion, extraction or decoction of the plant does not pose a health hazards as the plant is shown to be non-toxic.

\section{REFERENCES}

1. Nosheen Akhtar, Ihsan-ul-Haq, Bushra Mirza Arabian, Phytochemical analysis and comprehensive evaluatio $\mathrm{n}$ of antimicro bial and antioxidant propertie $\mathrm{s}$ of 61 medicinal plant species J. Chem. 2018, 11: 1223-1235.

2. Shanmugapriya S.A.T and Elamaran M, 2017Phytochemical Screening and Elemental
Analysis of Dodonaea Angustifolia Leaves

Extract, IJRASET, 5(VIII): 1529-1533

3. Adeyemi MMH. The potential of secondary metabolites in plant material as deterrents against insect pests: A review. African J. Pure and Applied Chem.. 2010; 4(11):243-246.

4. Chowanski S, Adamski Z, Marciniak P, Rosinski $\mathrm{G}$, Büyükgüzel $\mathrm{E}$, Büyükgüzel $\mathrm{K}$ et al. A review of bioinsecticidal activity of Solanaceae alkaloids. Toxins. 2016; 8:1-28.

5. Gupta, M.P. P. N. Solis, A. J. Calderon, F. Guinneau - Sinclair, M. Correa, C., Guerra, C. Gladames, A. Espinosa, G. L. Alvenda, G. Robles, R. Olampo J Ethnopharmacol 96 (2005) 389.

6. Salma A. El- Sawi, Hemaia M. Motawe, Salah S. Ahmad, Mohamed E. Ibrahim Survey and Assessment of Chemical Composition and Biological Activity of Some Wild Plants Growing in the Egyptian Eastern Desert, $J$. M ater. E nviron. Sci., 201 8, 9(5): 1495- 1502.

7. Rojas, J.J. V. J.Ochoa, S. A Ocampo, J. F. Muñoz, BMC Complement Altern Med 2006, $6: 2$.

8. Basile, A., L. Ferrara, M.D. Pezzo, G. Mele, S. Sorbo, P. Bassi and D. Montesano, 2005. Antibacterial and antioxidant activities of ethanol extract from Paullinia cupana Mart. J. Ethnopharmacol., 102: 32-36.

9. Mya Mu Aye, Hnin Thanda Aung, Myint Myint Sein and Chabaco Armijos. 2019. A Review on the Phytochemistry, Medicinal Properties and Pharmacological Activities of 15 Selected Myanmar Medicinal Plants. Molecules 2019, 24, 293.1-134.

10. Schumacher, H., Bosque, M.A., Domingo, J.L. and Corbella, J. (1991). Dietary intake of lead and cadmium from foods in Tarragona Province, Spain. Bull.Environ. Contaminants Toxicol., 46:320-328.

11. Harborne, J.B., 1998. Phytochemical methods: A Guide to Modern Techniques of Plant Analysis. Chapman and Hall Ltd. London. Pp. 49-188.

12. Raaman, N., 2006. Phytochemical techniques. New India Publishing agency, New Delhi, India. pp: 306. 
13. Sofowora, A., 1993. Medicinal plants and Traditional medicine in Africa.2nd Edn.John Wily and Sons. New York. pp. 6-56.

14. Wagner, H., 1993. Pharmazeutische Biologie, Drogen und ihre Inhaltsstoffe. Gustav Fischer Verlag, Stuttgart-New York, pp: 527-543.

15. Wagner, H., S. Baldt and E.M. Zgainski, 1996. Plant drug analysis. Berlin: Springer, pp: 73-74.

16. Ramakrishnan, S., K.G. Prasannan and R. Rajan, 1994. Text book of medicinal biochemistry. Orient Longman, New Delhi, India, pp: 582.

17. Harborne, J.B. 1973. Phytochemical Methods: A Guide to Modern Techniques of Plant Analysis. Chapman and Hall Ltd. London. Pp. 49-188.

18. Zhishen, J., T. Mengcheng and W. Jianming, 1999. The determination of flavonoid contents in mulberry and their scavenging effects on superoxide radicals. Food Chem., 64: 555-559.

19. Singleton, V.L., R. Orthofer and R.M. LamuelaRaventos, 1999. Analysis of total phenols and other oxidation substrates and antioxidants by means of Folin-Ciocalteau reagent. Methods in Enzymology, 299: 152-178.

20. Obadoni, B.O. and P.O. Ochuko, 2001. Phytochemical studies and Comparative efficacy of the crude extracts of some homeostatic plants in Edo and Delta States of Nigeria. Global J. Pure Appl. Sci., 8: 203-208.

21. Shahi, S.K., A.C. Shukla, A.K. Bajaj, G. Medgely and A. Dixit, 1999. Broad spectrum antimycotic drug for the control of fungal infection in human beings. Cur. Sci., 76:836839.

22. Rafiqul I, Rahman MS, Rahman SM 2015. GCMS analysis and antibacterial activity of
Cuscuta reflexa against bacterial pathogens. Asian Pac J Trop Dis.5(5):399-403.

23. Julsing M.K., and A. Koulman, H.J. Woerdenbag 2006.Combinatorial biosynthesis of med-icinal plant secondary metabolites, Biomol. Eng. 23: 265-279.

24. Mohana, D.C. and K.A. Raveesha, 2006. Antibacterial activity of Caesalpinia coriaria (Jacq.)Willd.against plant pathogenic Xanthomonas pathovars: an eco-friendly approach. J. Agric. Technol., 2: 317-327.

25. Lokhandea, R.S., P.U. Singare and M.L. Andhelea, 2010. Analysis of Trace Elements in Some Medicinal Plants by NAA and AAS Techniques, Radiochemistry, 52(3): 264-267.

26. Adumanya, O.C.U. A.A. Obiloma, E.B. Essien, 2015. Proximate, vitamins and mineral composition of Salacia senegalensis Lam (DC) leaves, Open. J. Res., 2: 92 -105.

27. Julian-Loaeza, A.P. N.E. Santos-Sanchez, R. Valadez-Blanco, B.S. Sanchez-Guzman, R. Salas-Coronado, 2011. Chemical composition, color, and antioxidant activity of three varieties of Annona diversifoliaSafford fruits, Ind. Crop. Prod. 34: 1262-1268.

28. Korc, M., 1988. Manganese Homeostasis in Human and its Role in Disease states. In: Prasad, A.S. (Ed.) Essential and Toxic Trace Elements in Human Health and Disease. Alan R. Liss Inc. New York, pp: 253-264.

29. Vaughan, J.G. and P.A. Judd, 2003. The Oxford Book of Health Foods: A Comprehensive Guide to Natural Remedies. 1st Edn., Oxford University Press, New York, pp: xvii. 